\title{
DIETHANOLAMIDE DERIVATIVES AS A POTENTIAL ENHANCED OIL RECOVERY AGENT FROM INDONESIAN CASTOR OIL AND USED FRYING OIL: ISOLATION, SYNTHESIS, AND EVALUATION AS NONIONIC BIOSURFACTANTS
}

\author{
T. D. Wahyuningsih" ${ }^{1, *}$, Y. S. Kurniawan' ${ }^{1}$, S. Amalia ${ }^{1}$, T. A. K. Wardhani ${ }^{1}$ \\ and C. E. S. Muriningsih ${ }^{1}$ \\ ${ }^{1}$ Department of Chemistry, Faculty of Mathematics and Natural Sciences, \\ Universitas Gadjah Mada, Yogyakarta-55281, Indonesia \\ *E-mail: tutikdw@ugm.ac.id
}

\begin{abstract}
Mono-, di- and trihydroxy fatty acids were reacted in a free-solvent amidation reaction with diethanolamine to obtain the derivative of dialkanolamides.The ricinoleic acid and 9,10,12-trihydroxystearic acid were isolated and prepared from Indonesian castor oil, while 9,10-dihydroxystearic acid was synthesized from the used frying oil. Amidation reaction of methyl ricinoleate, 9,10-dihydroxystearic acid and 9,10,12-trihydroxystearic acid gave the dialkanolamide derivatives in $93.10,49.66$, and $38.78 \%$ yield, respectively. The chemical structure of the synthesized products was elucidated by FTIR and GC-MS through silylation method. The prepared compounds were evaluated for their physicochemical properties as nonionic biosurfactant such as Hydrophilic-Lyophilic Balance value, interfacial tension, critical micelle concentration, foam stability, emulsification index, and emulsion stability. It was found that more hydroxyl groups contribute to a higher Hydrophilic-Lyophilic Balance value, foam stability, emulsification index, and lower interfacial tension.
\end{abstract}

Keywords: Diethanolamide, Biosurfactant, Castor Oil, Used Frying Oil, Free-Solvent Synthesis.

(c) RASĀYAN. All rights reserved

\section{INTRODUCTION}

Nowadays many researchers are putting efforts on renewable energy such as solar cell, biodiesel and so $\mathrm{on}^{1-4}$. However, energy demand based on crude oil is still dominant, especially in developing countries. For example, Akhmad and Amir reported that $88 \%$ of national energy factories depend on crude oil supply in Indonesia ${ }^{5}$. Many projects are employed to find new crude oil sources and enhance the oil recovery from the available resources ${ }^{6-8}$. Enhanced oil recovery is a process which the surfactant was used to make a stable emulsion between water and crude oil thus the remaining crude oil in the sources can be taken out and utilized $^{9,10}$.

The surfactant is a chemical compound with hydrophilic and lyophilic parts in the same molecular structure. Petroleum sulfonate is an example of the commercial enhanced oil recovery agent. However, it is prepared from the crude oil through sulfonation reaction. To suppress the competition of using crude oil as surfactant sources as well as to develop a biodegradable surfactant, some novel biosurfactants have been prepared and evaluated $^{6-8,11-14}$. Some biosurfactants have been developed and reported ${ }^{15,16}$, however, the recent interest in the nonionic surfactants based on edible oil keeps growing on due to their high thermal stability, biodegradability and high chemical stability ${ }^{14,17-18}$. The physicochemical properties of biosurfactants depend on the lengths of the alkyl chains as well as the presence of the substituents on the alkyl chains.

Awang et al. (2006) synthesized 9,10-dihydroxystearyl-ethanolamide and 9,10-dihydroxystearylpropanolamide. These monoalkanolamide derivatives are potential because they are stable emulsifiers and chemically stable in alkaline media but could be degraded more than 50\% in 10 days. They reported that

Rasayan J. Chem., 12(2), 741-748(2019)

http://dx.doi.org/10.31788/RJC.2019.1225140

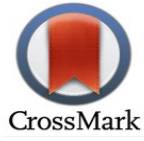


9,10-dihydroxystearyl-ethanolamide had better foaming power and stability than that of 9,10dihydroxystearyl-propanolamide ${ }^{19}$. However, further development is still required to design better biosurfactants from their results.

In this work, we prepared diethanolamide derivative from the commercial sources, i.e., Indonesia castor oil and used frying oil. Castor oil consists of up to $90 \%$ of ricinoleic acid (12-hydroxyoctadec-9-enoic acid) ${ }^{20-}$ ${ }^{21}$ while used frying oil contains $44 \%$ of oleic acid (octadic-9-enoic acid) ${ }^{22}$. Both fatty acids can be isolated through a simple transesterification reaction. Then the fatty acids were modified to obtain mono-, di- and trihydroxy fatty acids and further reacted with diethanolamine to produce ricinoleyl-diethanolamide (RDEA), 9,10-dihydroxystearyl-diethanolamide (DHS-DEA), and 9,10,12-trihydroxystearyl-diethanolamide (THS-DEA). The reaction scheme is shown in Fig.-1. The physicochemical properties of the synthesized products were evaluated as nonionic biosurfactants, such as HLB value, interfacial tension, critical micelle concentration, foam stability, emulsification index, and emulsion stability.

(a)

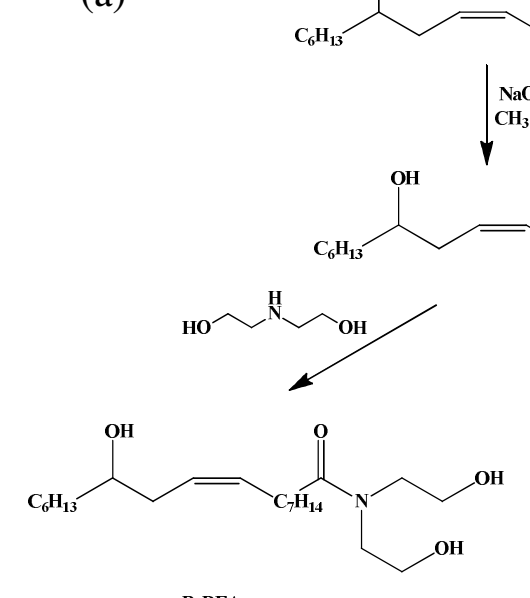

R-DEA
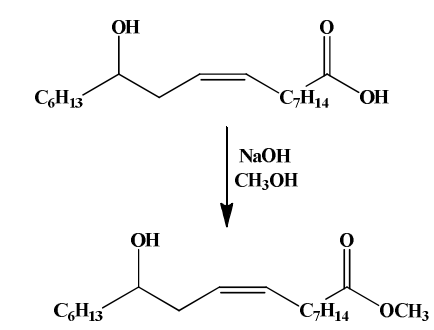

(1)

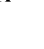

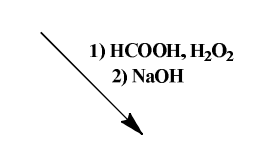

(b)
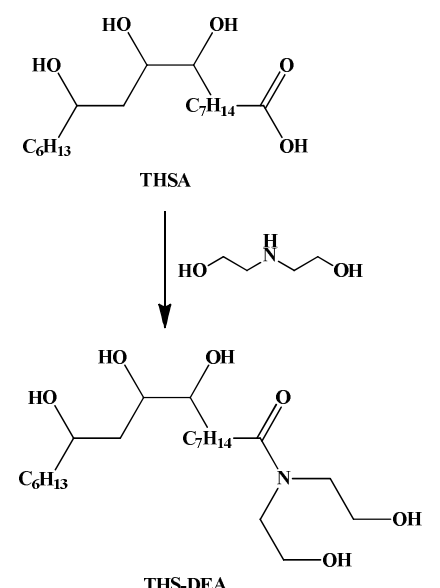

THS-DEA
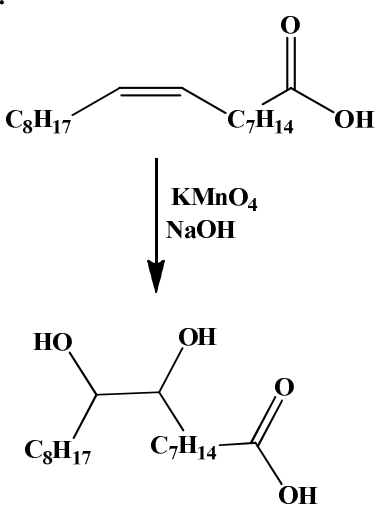

DHSA<smiles>CC(C)CCCCO</smiles>

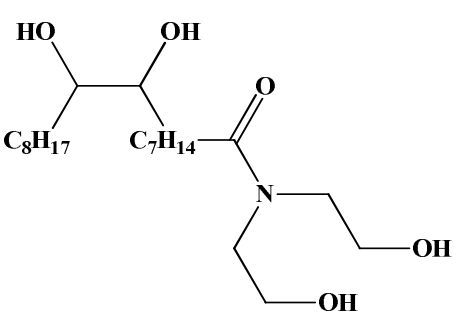

DHS-DEA

Fig.-1: Reaction Scheme of the Synthesis of the Diethanolamide Derivatives from (a) Ricinoleic Acid Derived from Castor Oil and (b) Oleic Acid Derived from Used Frying Oil.

\section{General}

\section{EXPERIMENTAL}

Diethanolamine, chloroform, methanol, ethyl acetate, acetonitrile, sodium hydroxide, potassium hydroxide, hydrochloric acid, potassium iodide, sodium thiosulfate and anhydrous sodium sulfate - were of analytical grade from Merck, Germany and used as received, while N,O-bis(trimethylsilyl)trifluoroacetamide (BSTFA) was received from Aldrich, Germany. The castor oil was obtained from Brataco, while used frying oil was collected from Yogyakarta. Fourier Transform Infrared (FTIR) spectra of the synthesized compounds were recorded on Prestige-21 FTIR Spectrometers using KBr discs. ${ }^{1} \mathrm{H}$ NMR spectra were obtained on a Jeol JNM-ECA $500(500 \mathrm{MHz})$ spectrometer. Mass spectra were recorded on Shimadzu GCMS QP 2010S (EI) at UGM. Column chromatography was carried out using Merck silica gel (230-400 mesh ASTM), while preparative thin layer chromatography was performed using Merck silica gel (7730 60 $\left.\mathrm{GF}_{254}\right)$. 


\section{Transesterification of Castor oil}

Sodium hydroxide $(1.06 \mathrm{~g})$ in methanol $\left(10 \mathrm{~cm}^{3}\right)$ was added into castor oil $(100.00 \mathrm{~g})$ and the mixture was heated at $333 \mathrm{~K}$ for $90 \mathrm{~min}$. After the reaction, the mixture was cooled down to room temperature for 60 min. The mixture was neutralized with $6 \mathrm{M} \mathrm{HCl}\left(7 \mathrm{~cm}^{3}\right)$ and washed three times with distilled water $(900$ $\left.\mathrm{cm}^{3}\right)$. The organic phase was separated and dried to give $72.53 \mathrm{~g}$ of methyl ricinoleate as a yellowish liquid (68.70\% yield). FTIR (Wavenumber/ $\left.\left.\mathrm{cm}^{-1}\right): 3433(\mathrm{OH}), 2924(\mathrm{C}-\mathrm{H} \mathrm{sp})^{3}\right), 1736\left(\mathrm{C}=\mathrm{O}\right.$ ester), $1437\left(-\mathrm{CH}_{2}-\right)$, 1172 (C-O-C ester) and 725 (cis alkene). GC: $86.99 \%$ of methyl ricinoleate (Retention time, $\mathrm{R}_{\mathrm{t}}=8.29 \mathrm{~min}$ ).

\section{Amidation of Methyl Ricinolate with Diethanolamine}

The mixture of methyl ricinoleate $(20.00 \mathrm{~g}, 64 \mathrm{mmol})$ and diethanolamine $(13.46 \mathrm{~g}, 128 \mathrm{mmol})$ was heated at $428 \mathrm{~K}$ for $10 \mathrm{~h}$. After the reaction, chloroform:methanol $1: 1\left(30 \mathrm{~cm}^{3}\right)$ was added to the mixture. The organic phase was dried and concentrated. The R-DEA product was obtained as a yellow-brownish viscous liquid $\left(22.94 \mathrm{~g}, 93.10 \%\right.$ yield). FTIR (Wavenumber/cm $\left.{ }^{-1}\right)$ : $3372(\mathrm{OH}), 2924\left(\mathrm{C}-\mathrm{H} \mathrm{sp}{ }^{3}\right), 1620(\mathrm{C}=\mathrm{O}$ amide), $1466\left(-\mathrm{CH}_{2}-\right), 1211$ (C-N amide) and 718 (cis alkene). To analyze the purity of the synthesized product, diethanolamide derivative $(0.1 \mathrm{mg}, 0.260 \mu \mathrm{mol})$ and BSTFA $(0.1 \mathrm{mg}, 0.389 \mu \mathrm{mol})$ in acetonitrile $\left(0.2 \mathrm{~cm}^{3}\right)$ were reacted at $338 \mathrm{~K}$ for $1 \mathrm{~h}$. After the reaction, the solution was injected into GC-MS spectrometer. GC: 80.90\% of R-DEA ( $\left.\mathrm{R}_{\mathrm{t}}=24.62 \mathrm{~min}\right)$. MS: $514\left(\mathrm{M}^{+}-15\right)$, 415, 354, 248, 214, 160, 146 (base peak), 130, 116.

\section{Synthesis of 9,10,12-Trihydroxystearic Acid (THSA) from Methyl Ricinoleate}

This reaction was carried out in 2 steps, i.e., epoxidation reaction of methyl ricinoleate and ring opening reaction in the alkaline condition ${ }^{23}$. First, the mixture of methyl ricinoleate $(11.58 \mathrm{~g}, 32 \mathrm{mmol})$ and formic acid $(35.14 \mathrm{~g}, 760 \mathrm{mmol}$ ) was stirred for $15 \mathrm{~min}$ at room temperature. The mixture was cooled down to 283 $\mathrm{K}, 30.0 \% \mathrm{H}_{2} \mathrm{O}_{2}$ solution $\left(46 \mathrm{~cm}^{3}, 450 \mathrm{mmol}\right)$ was added dropwise and the mixture was stirred for another $3 \mathrm{~h}$. The organic phase was diluted with diethyl ether $\left(40 \mathrm{~cm}^{3}\right)$ and washed with distilled water until neutral. The solvent was removed in vacuo. The ring opening reaction was carried out by dissolving the obtained residue in $2.0 \mathrm{M} \mathrm{NaOH}$ solution $\left(20 \mathrm{~cm}^{3}\right)$ and heating at $373 \mathrm{~K}$ for $2 \mathrm{~h}$. The mixture was neutralized with $2.0 \mathrm{M} \mathrm{HCl}$ and the formed precipitation was recrystallized from ethanol to obtain THSA as a yellowish solid (22.94 g, 93.10\% yield). Melting point: $110.0-114.0^{\circ} \mathrm{C}$. FTIR (Wavenumber/ $\mathrm{cm}^{-1}$ ): $3372(\mathrm{OH}), 2924$ $\left(\mathrm{C}-\mathrm{H} \mathrm{sp}^{3}\right), 1697\left(\mathrm{C}=\mathrm{O}\right.$ carboxylic acid), and $1466\left(-\mathrm{CH}_{2}-\right) .{ }^{1} \mathrm{H}-\mathrm{NMR}$ (DMSO-d6, Chemical shift/ppm): 0.86 (t, 3H, $\mathrm{CH}_{3}$ ), 1.24-1.48 (m, 24H, - $\mathrm{CH}_{2}-$ ), 2.18 (t, 2H, $\mathrm{CH}_{2} \mathrm{COO}$ ), 3.18-3.58 (m, 3H, CH-OH). The GC-MS analysis was carried out by derivatization of the product with BSTFA as described above. GC: $89.29 \%$ of THSA $\left(\mathrm{R}_{\mathrm{t}}=19.73 \mathrm{~min}\right)$. MS: $445\left(\mathrm{M}^{+}-176\right), 403,390,355,329,317,301,261,227,217,187$ (base peak), 147, 73.

\section{Amidation of THSA with Diethanolamine}

The mixture of THSA $(1.16 \mathrm{~g}, 3.5 \mathrm{mmol})$ and diethanolamine $(3.68 \mathrm{~g}, 35 \mathrm{mmol})$ was heated at $443 \mathrm{~K}$ for 6 h. After the reaction, chloroform:methanol 1:1 $\left(30 \mathrm{~cm}^{3}\right)$ was added to the mixture. The organic phase was dried and concentrated. The THS-DEA product was obtained as a yellowish viscous liquid $(0.57 \mathrm{~g}, 38.78 \%$ yield). FTIR (Wavenumber/cm $\left.{ }^{-1}\right): 3356(\mathrm{OH}), 2928\left(\mathrm{C}-\mathrm{H} \mathrm{sp}{ }^{3}\right), 1620(\mathrm{C}=\mathrm{O}$ amide $), 1466\left(-\mathrm{CH}_{2}-\right)$ and 1049 (C-N amide). ${ }^{1} \mathrm{H}-\mathrm{NMR}\left(\mathrm{CDCl}_{3}\right.$, Chemical shift/ppm): 0.84 (t, 3H, $\left.\mathrm{CH}_{3}\right), 1.22-1.58\left(\mathrm{~m}, 24 \mathrm{H},-\mathrm{CH}_{2}-\right), 2.29$ (t, 2H, $\left.\mathrm{CH}_{2} \mathrm{COO}\right), 2.64$ (s, 3H, OH), 3.46-3.70 (m, 8H, CH-OH \& $\left.\mathrm{N}\left(\mathrm{CH}_{2} \mathrm{CH}_{2} \mathrm{OH}\right)_{2}\right), 4.23$ (s, 2H, OH). The GC-MS analysis was carried out by derivatization of the product with BSTFA as described above. GC: 54.04\% of THS-DEA $\left(\mathrm{R}_{\mathrm{t}}=28.04 \mathrm{~min}\right)$. MS: $572\left(\mathrm{M}^{+}-208\right), 476,386,248,201,187,146,116,73$ (base peak).

\section{Transesterification of used Frying Oil}

Transesterification of used frying oil was carried out in a similar procedure as transesterification of castor oil to obtain $72.23 \mathrm{~g}$ of methyl esters as a yellowish liquid ( $82.94 \%$ yield). FTIR (Wavenumber $\left./ \mathrm{cm}^{-1}\right): 2924$ $\left(\mathrm{C}-\mathrm{H} \mathrm{sp}^{3}\right), 1743\left(\mathrm{C}=\mathrm{O}\right.$ ester), $1458\left(-\mathrm{CH}_{2}-\right), 1165$ (C-O-C ester) and 725 (cis alkene). GC: $44.91 \%$ of methyl palmitate $\left(t_{R}=26.57 \mathrm{~min}\right), 47.47 \%$ of methyl oleate $\left(R_{t}=30.07 \mathrm{~min}\right)$, and $3.87 \%$ of methyl stearate $\left(R_{t}=\right.$ $30.53 \mathrm{~min})$.

\section{Synthesis of 9,10-Dihydroxystearic Acid (DHSA)}

The methyl ester $(28.00 \mathrm{~g}, 99 \mathrm{mmol})$ and $10.00 \%$ sodium hydroxide solution in ethanol $(218 \mathrm{mmol})$ were mixed and refluxed for $2 \mathrm{~h}$. The mixture was acidified with $6.0 \mathrm{M} \mathrm{HCl}$ until the $\mathrm{pH} 2.0$ and then extracted 
with diethyl ether $\left(150 \mathrm{~cm}^{3}\right)$. The organic phase was dried and concentrated to give $23.46 \mathrm{~g}$ of fatty acids as a yellowish liquid $\left(88.46 \%\right.$ yield). FTIR (Wavenumber $\left./ \mathrm{cm}^{-1}\right)$ : broad peak at 3400-2500 (OH), 2924 (C$\left.\mathrm{H} \mathrm{sp}{ }^{3}\right), 1705$ (C=O carboxylic acid), and $1458\left(-\mathrm{CH}_{2}-\right)$. The obtained fatty acid was hydrolyzed with potassium permanganate in the alkaline condition in the same procedure as previously reported ${ }^{19}$. The DHSA was obtained as a white powder (1.35 g, 76.27\% yield). Melting point: $127.0-128.0{ }^{\circ} \mathrm{C}$. FTIR (Wavenumber $\left./ \mathrm{cm}^{-1}\right)$ : broad peak at 3276 (OH alcohol), 3209 (OH carboxylic acid), $2916\left(\mathrm{C}-\mathrm{H} \mathrm{sp}{ }^{3}\right), 1697$ $\left(\mathrm{C}=\mathrm{O}\right.$ carboxylic acid), and $1435\left(-\mathrm{CH}_{2}-\right)$.

\section{Amidation of DHSA with Diethanolamine}

The mixture of DHSA (1.16 g, $3.7 \mathrm{mmol})$ and diethanolamine $(3.68 \mathrm{~g}, 37 \mathrm{mmol})$ was heated at $428 \mathrm{~K}$. The reaction time was set at $6 \mathrm{~h}$. After the reaction, chloroform: methanol 1:1 $\left(30 \mathrm{~cm}^{3}\right)$ was added to the mixture. The organic phase was dried and concentrated. The crude product was purified by column chromatography using chloroform: ethyl acetate 9:1 as eluent to yield the DHS-DEA as a viscous brown liquid (0.74 $\mathrm{g}$, $49.79 \%$ yield). FTIR (Wavenumber $\left./ \mathrm{cm}^{-1}\right)$ : broad peak at $3309(\mathrm{OH}$ alcohol $), 2916\left(\mathrm{C}-\mathrm{H} \mathrm{sp}{ }^{3}\right), 1620(\mathrm{C}=\mathrm{O}$ amide), $1435\left(-\mathrm{CH}_{2}-\right)$, and 1064 (C-N amide). The GC-MS analysis was carried out by derivatization of the product with BSTFA as described above. GC: $70.00 \%$ of DHS-DEA $\left(\mathrm{R}_{\mathrm{t}}=57.23 \mathrm{~min}\right)$. MS: $586\left(\mathrm{M}^{+}-106\right)$, 476, 386, 291, 284, 215, 146, 116, 73 (base peak).

\section{Physicochemical Properties of the Synthesized products as Biosurfactant}

Hydrophilic-Lyophilic Balance (HLB) value

The HLB value was measured by Griffin method $^{24}$ and the mathematic formula was shown as equation (1), where $\mathrm{H}$ is the number of hydrophilic groups on the nonionic biosurfactant and $\mathrm{L}$ is the number of lyophilic groups on the nonionic biosurfactant.

\section{Interfacial Tension Measurement}

$$
H L B=7+\sum H+\sum L
$$

Interfacial tension of the synthesized compound was measured by capillary rise method as previously described ${ }^{25}$. In this procedure, ethanol was used as a blank, and the sample concentration was varied at 0.5 , 1.0 and $1.5 \mathrm{~g} \mathrm{dm}^{-3}$ in ethanol. Briefly, the sample was added into the tube, and the pressure was introduced to the capillary glass thus the liquid position inside the capillary glass was increased. When the pressure was released, the liquid inside the capillary glass went down due to gravitational force and reached the final position. The difference between the position of the liquid inside the capillary glass and outside the tube was measured. The measurement of each sample was done with three replications.

\section{Critical Micelle Concentration Measurement}

Critical micelle concentration of the synthesized compound was measured by turbidimetry method at 301 $\mathrm{K}$ in a similar manner as reported before ${ }^{26}$. Briefly, first, the turbidimeter apparatus was calibrated by using $\mathrm{AMCO}^{\mathrm{TM}} 20201.0 \mathrm{NTU}$ and $\mathrm{AMCO}^{\mathrm{TM}} 202010 \mathrm{NTU}$, then the turbidity value was set at 1.0 and $10 \mathrm{NTU}$, respectively. The turbidity of the sample at $0.5-2.0 \mathrm{~g} \mathrm{dm}^{-3}$ concentration in distilled water was measured in three replications.

\section{Foam Stability Measurement}

The synthesized product at 5,10 and $15 \mathrm{~g} \mathrm{dm}^{-3}$ concentration in distilled water $\left(20 \mathrm{~cm}^{3}\right)$ was stirred for 1 hat room temperature. The height and the volume of the formed foam on the liquid surface were measured for $100 \mathrm{~min}$. The foam stability was investigated from the graph between foam volume versus the investigation time (0-100 $\mathrm{min})$.

\section{Emulsification Index and Emulsion Stability Measurement}

The measurement of emulsification index and emulsion stability was carried out with gasoline and water in 1:1 volume ratio as previously described ${ }^{27}$. The synthesized product was dissolved in distilled water (10 $\mathrm{cm}^{3}$ ) at $1 \mathrm{~g} \mathrm{dm}^{-3}$ concentration. The aqueous phase was mixed with gasoline and stirred for $5 \mathrm{~min}$. The emulsion height was investigated for 1, 2, 3 and 4 days. Emulsification index was determined by using equation (2). 
RASĀYAN J. Chem.

Vol. 12 | No. 2 |741 - 748| April - June | 2019

$$
\text { Emulsification index }=\frac{\text { Height of the emulsified layer }}{\text { Height of the total liquid column }} \cdot 100 \%
$$

\section{Synthesis of R-DEA Compound}

\section{RESULTS AND DISCUSSION}

In this work, methyl ricinoleate was successfully isolated through a simple transesterification reaction at $333 \mathrm{~K}$ for $90 \mathrm{~min}$ in $68.70 \%$ yield with $86.99 \%$ purity. The FTIR spectrum of the isolated ricinoleic acid was similar to the FTIR spectrum of the standard ricinoleic acid (data not shown). In addition, the GC chromatogram showed the same retention time for the standard ricinoleic acid and isolated ricinoleic acid $\left(\mathrm{R}_{\mathrm{t}}=8.29 \mathrm{~min}\right)$.

Amidation of methyl ricinoleate with diethanolamine has been performed in mol ratio 1:2 without any solvent (free-solvent reaction) and temperature of the reaction is set at higher than $400 \mathrm{~K}$ to avoid the formation of amino ester, amino soap, and ester amide. FTIR spectra of R-DEA compound showed that $\mathrm{OH}$ peak appeared at $3372 \mathrm{~cm}^{-1}$, while $\mathrm{C}-\mathrm{N}$ and $\mathrm{C}=\mathrm{O}$ stretching of amide functional groups exist at 1211 and $1620 \mathrm{~cm}^{-1}$, respectively ${ }^{17}$. Amidation product was analyzed by GC-MS via silylation method. The sample was dissolved in acetonitrile, and it was mixed with BSTFA. Complete silylation reaction was achieved after heating up the mixture at $333 \mathrm{~K}$ for $1 \mathrm{~h}$. Silylation reaction was performed to decrease the high boiling point of R-DEA, so that the chemical structure of R-DEA can be analyzed by GC-MS spectrometer. GC Chromatogram showed that the silylated R-DEA was detected at retention time $24.62 \mathrm{~min}$ in $80.90 \%$ purity. Mass spectra revealed that the ion molecular is absent at $\mathrm{m} / \mathrm{z}=606$. However, the presence of $\mathrm{m} / \mathrm{z}=470$ from losing fragment $\mathrm{CH}_{3} \mathrm{CH}_{2}$ and $\mathrm{CH}_{2} \mathrm{OSi}\left(\mathrm{CH}_{3}\right)_{3}$ and the presence of $\mathrm{m} / \mathrm{z}=400$ from the fragmentation of $\left(\mathrm{CH}_{2}\right)_{6}-\mathrm{CH}\left(\mathrm{OSi}\left(\mathrm{CH}_{3}\right)_{3}\right)-\mathrm{CH}_{2}$ gave an indication the correct structure of R-DEA.

\section{Synthesis of THS-DEA Compound}

The THS-DEA compound was prepared from the three-step reaction, i.e., epoxidation of methyl ricinoleate, ring opening reaction of epoxidized methyl ricinoleate, and amidation of THSA. Epoxidation reaction was carried out by reacting methyl ricinoleate with $30.0 \% \mathrm{H}_{2} \mathrm{O}_{2}$ in the presence of formic acid. The epoxide ring was located at carbon 9 and 10 of methyl ricinoleate and further hydrolyzed in the alkaline condition to obtain THSA as a yellowish solid. The THSA was reacted with diethylamine to produce THS-DEA as a yellowish viscous liquid in $38.78 \%$ yield. After the silylation reaction, the GC chromatogram showed the presence of the diethanolamide product at retention time $28.19 \mathrm{~min}$ in $54.04 \%$ purity. Even though the molecular ion of silylated THS-DEA did not appear on the MS spectra, the characteristic fragmentation at $\mathrm{m} / \mathrm{z}=476(85 \%)$ for diethanolamide from fragment lost two hydroxyls TMS (tetramethylsilane) proven that the structure was consistent as THS-DEA. The infrared frequencies were in agreement and further supported by ${ }^{1} \mathrm{H}-\mathrm{NMR}$ spectrum showing two types of hydroxyl groups at 2.64 and $4.23 \mathrm{ppm}$, respectively. Meanwhile, the multiplet peaks resonance at $3.46-3.70 \mathrm{ppm}$ for eight protons was assigned to the methylene $\left(\mathrm{CH}_{2}\right)$ at the diethanol part and methine $(-\mathrm{CH})$ attached to a hydroxyl group. From this characterization, it was confirmed that THS-DEA had been successfully synthesized.

\section{Synthesis of DHS-DEA Compound}

DHS-DEA compound was prepared prior to the reaction with diethanolamine, and in this research, the DHSA could be produced in two-step reaction from used frying oil, i.e., hydrolysis of triglyceride and followed by low-temperature oxidation with $\mathrm{KMnO}_{4}$. It was shown that a mixture of isolated fatty acids (with $47.47 \%$ of oleic acid) could produce DHSA in $87.00 \%$ yield based on the amount of oleic acid or $76.27 \%$ yield from overall fatty acids. DHS-DEA was synthesized from the same procedure as above, by the use of DHSA and diethanolamine (Fig.-1(b)). The DHS-DEA was obtained as a viscous brown liquid in $49.79 \%$ yield. The reaction yield was decreased by increasing the number of hydroxyl groups on the fatty acid backbone ( $93.10 \%$ for monohydroxyfatty acid (R-DEA), $49.79 \%$ for dihydroxy fatty acid (DHS-DEA) and $38.78 \%$ for trihydroxy fatty acid (THS-DEA)). FTIR spectra of DHS-DEA showed the same absorption as R-DEA and THS-DEA at 1620 and $1064 \mathrm{~cm}^{-1}$ for $\mathrm{C}=\mathrm{O}$ amide and $\mathrm{C}-\mathrm{N}$ stretching, respectively. Furthermore, silylated DHS-DEA was shown at a retention time of $57.23 \mathrm{~min}$ in $70 \%$ purity. Mass spectra revealed that the ion molecular is absent at $\mathrm{m} / \mathrm{z}=692$. However, the presence of $\mathrm{m} / \mathrm{z}=476$ from losing 
fragment $\mathrm{CH}_{3}\left(\mathrm{CH}_{2}\right)_{7} \mathrm{CHOTMS}$ and $\mathrm{m} / \mathrm{z}=386$ from the fragmentation of $\left(\mathrm{CH}_{2}\right)_{2}-\mathrm{C}=\mathrm{ON}\left(\mathrm{CH}_{2} \mathrm{CH}_{2} \mathrm{OTMS}\right)$ indicated the correct chemical structure of DHS-DEA.

\section{Physicochemical Properties of the Diethanolamide Derivative as Nonionic Biosurfactants}

At first, the HLB value was calculated from equation (1) in which the value for tertiary amine, hydroxyl, and alkyl (either $-\mathrm{CH}-$ or $-\mathrm{CH}_{2}-$ or $-\mathrm{CH}_{3}$ ) groups are $9.4,1.9$ and -0.475 , respectively. It was found that HLB value for R-DEA, DHS-DEA, and THS-DEA are 12.125, 14.025 and 15.925, respectively. It is clear that the HLB value of the synthesized compounds is become higher by increasing the number of hydroxyl groups. According to Holmberg et al. (2002), all the synthesized compounds in this work are categorized as surfactant because the HLB value is higher than in $12^{24}$. However, since the purity of THS-DEA is quite low $(54.04 \%)$, further evaluation of physicochemical properties as nonionic biosurfactant was carried out only for R-DEA and DHS-DEA compounds.

The density and interfacial tension values of R-DEA and DHS-DEA are shown in Table-1 and Table-2, respectively. It was found that the density of R-DEA and DHS-DEA is similar due to similar chemical structure (Table-1). From Table-2, the interfacial tension decreased by increasing the surfactant concentrations. Even though the interfacial tension of both derivatives is similar at $0.5 \mathrm{~g} \mathrm{dm}^{-3}$ concentration, the interfacial tension of DHS-DEA is lower than R-DEA at higher concentration due to the addition of one hydroxyl groups at the alkyl chain. Addition of hydroxyl functional groups stabilizes the Gibbs free energy on the surface of the liquid. Thus the interfacial tension was decreased ${ }^{21}$. Compared with monoethanolamide derivative which has interfacial tension at $30 \mathrm{mN} \mathrm{m}^{-1}{ }^{17}$, the interfacial tension of diethanolamide derivatives is lower confirming that the presence of the hydroxyl groups is critical either on fatty acid alkyl chain or on amide part.

Table-1: Density of R-DEA and DHS-DEA at 0.0-1.5 $\mathrm{g} \mathrm{dm}^{-3}$ Concentration in Ethanol

\begin{tabular}{c|c|c}
\hline \multirow{2}{*}{ Concentration $\left(\mathrm{g} \mathrm{dm}^{-3}\right)$ in Ethanol } & \multicolumn{2}{|c}{ Density $\left(\mathrm{g} \mathrm{cm}^{-3}\right)$} \\
\cline { 2 - 3 } & \multicolumn{2}{|c}{$0.7825^{28}$} \\
\hline 0.0 & $0.7854 \pm 0.0015$ & $0.7854 \pm 0.0016$ \\
\hline 0.5 & $0.7858 \pm 0.0010$ & $0.7861 \pm 0.0012$ \\
\hline 1.0 & $0.7864 \pm 0.0006$ & $0.7865 \pm 0.0005$ \\
\hline 1.5 & \multicolumn{2}{|c|}{ RHS-DEA } \\
\hline
\end{tabular}

Table-2: Interfacial Tension of R-DEA and DHS-DEA at 0.0-1.5 $\mathrm{g} \mathrm{dm}^{-3}$ Concentration in Ethanol

\begin{tabular}{|c|c|c|}
\hline \multirow{2}{*}{ Concentration $\left(\mathrm{g} \mathrm{dm}^{-3}\right)$ in Ethanol } & \multicolumn{2}{|c|}{ Interfacial Tension $\left(\mathrm{mN} \mathrm{m}^{-1}\right)$} \\
\hline & R-DEA & DHS-DEA \\
\hline 0.0 & \multicolumn{2}{|c|}{$21.700^{28}$} \\
\hline 0.5 & $19.708 \pm 0.898$ & $20.207 \pm 0.454$ \\
\hline 1.0 & $18.167 \pm 0.899$ & $16.803 \pm 0.455$ \\
\hline 1.5 & $16.098 \pm 0.899$ & $14.189 \pm 1.576$ \\
\hline
\end{tabular}

The R-DEA and DHS-DEA biosurfactants were further investigated for their critical micelle concentration through turbidity method. The critical micelle concentration could be determined by a conductometry method. However, since the synthesized compounds belong to nonionic surfactants, so the turbidimetry gives more valid results.

The graph between turbidimetry and surfactant concentrations is shown in Fig.-2 (a). It shows that the critical micelle concentration for both derivatives is $1.5 \mathrm{~g} \mathrm{dm}^{-3}$ probably due to similar three-dimensional structures. The foam stability of the prepared biosurfactants was also evaluated to know the quality of biosurfactant to make stable foams. The results are shown in Fig.-2 (b). The resulted foam volume is larger when the added biosurfactant concentrations are higher. It was found that DHS-DEA makes more foam than R-DEA due to the addition of one hydroxyl group. The produced foam after biosurfactant addition to the distilled water for both derivatives is relatively stable until $100 \mathrm{~min}$ demonstrating that both derivatives show good quality to be applied as biosurfactants.

The last preliminary characterization of R-DEA and DHS-DEA is the evaluation of the emulsification index and emulsion stability for distilled water:gasoline system at 1:1 volume ratio. The results are listed in Table- 
3. The R-DEA shows lower emulsification index than DHS-DEA. It is because DHS-DEA has an additional hydroxyl group.
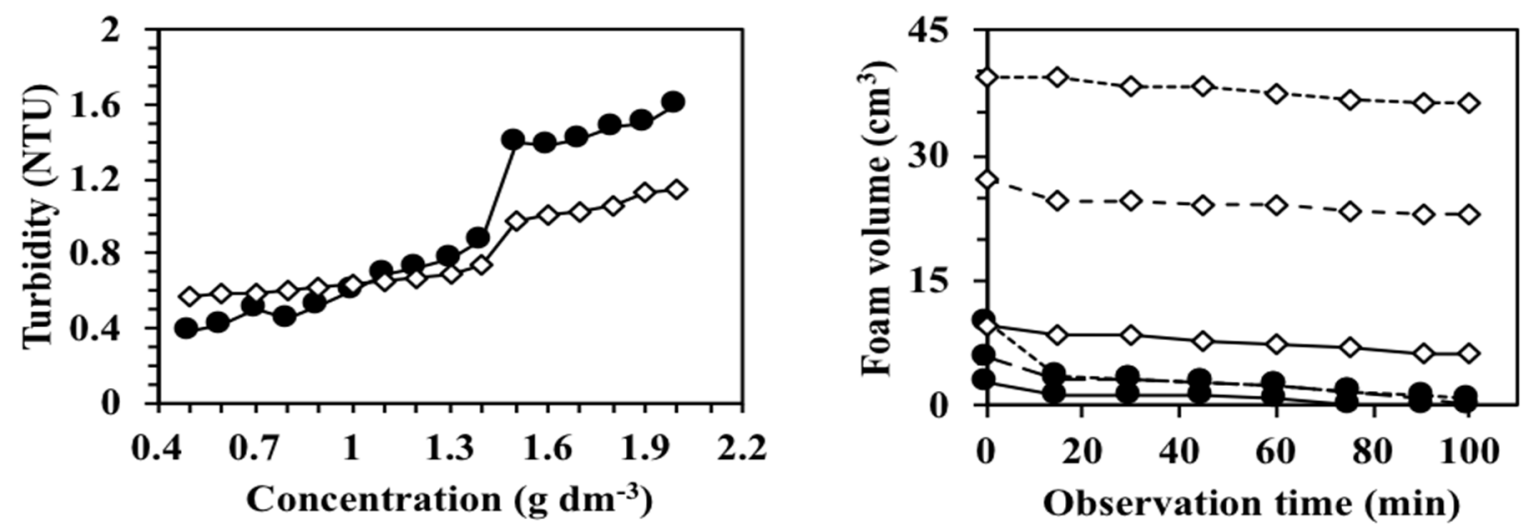

Fig.-2. (a) Turbidity Measurement to Determine the Critical Micelle Concentration of Biosurfactant. (b) Foam Stability Experiment of Biosurfactant at $5 \mathrm{~g} \mathrm{dm}^{-3}$ (solid line), $10 \mathrm{~g} \mathrm{dm}^{-3}$ (Dash Line), and $15 \mathrm{~g} \mathrm{dm}^{-3}$ (Dot Line) Concentration. Black Circle: R-DEA. White Diamond: DHS-DEA.

Therefore, DHS-DEA makes stable emulsion between distilled water and gasoline. The DHS-DEA biosurfactant works by decreasing the interfacial tension between distilled water and gasoline, thus the emulsification index was high $(>60.00 \%)$ even for 4 days observation. After 4 days, the emulsification index decreased only $4.00 \%$ which is remarkable. These findings are critical for biosurfactant and enhanced oil recovery field because the DHS-DEA derivatives were obtained from the commercial and cheap sources (castor oil and used frying oil) but they show good physicochemical properties as nonionic biosurfactant.

\begin{tabular}{c|c|c}
\multirow{2}{*}{$\begin{array}{c}\text { Table-3: Emulsification Index of R-DEA and DHS-DEA for 4 Days Observation } \\
\text { Observation Time } \\
\text { (day) }\end{array}$} & \multicolumn{2}{|c}{ Emulsification Index (\%) } \\
\cline { 2 - 3 } & R-DEA & DHS-DEA \\
\hline 1 & 10.00 & 68.00 \\
\hline 2 & 10.00 & 66.67 \\
\hline 3 & 10.00 & 65.33 \\
\hline 4 & 6.67 & 64.00 \\
\hline
\end{tabular}

\section{CONCLUSION}

In the present work, we successfully synthesized three diethanolamide derivatives, i.e., R-DEA, DHS-DEA and THS-DEA in 93.10, 49.66 and 38.78\% yield, respectively, from Indonesian castor oil and used frying oil. Amidation reaction of fatty acids with mono-, di- and trihydroxy groups was carried out in a simple free-solvent reaction. Addition of hydroxyl groups decreased the interfacial tension but increased HLB value, foam stability, emulsification index, and emulsion stability. It was because the hydroxyls decrease the Gibbs free energy on the surface of the liquid, so the biosurfactant activity and efficiency are increased. It was found that DHS-DEA is potential to be applied as the enhanced oil recovery agent because it makes stable emulsion between distilled water and gasoline with emulsification index in 64.00-68.00\% range and the emulsification index decreased only $4.00 \%$ after 4 days observation. Moreover, DHS-DEA was prepared from used frying oil which is cheap and abundant in Indonesia.

\section{ACKNOWLEDGMENT}

The authors acknowledge The Indonesian Directorate General of Higher Education (DIKTI) and Universitas Gadjah Mada (UGM) for the research grants.

\section{REFERENCES}

1. S. Tamrakar, R. Verma, S.K. Sar and C. Verma, Rasayan J. Chem., 12(2), 455(2019), DOI: 10.31788/RJC.2019.1225106

2. T.N. Sequeira and M.S. Santos, J. Clean. Prod., 192, 553(2018), DOI: 10.1016/j.jclepro.2018.04.190 


\section{RASĀYAN J. Chem.}

Vol. 12 | No. 2 |741 - 748| April - June | 2019

3. T.D. Wahyuningsih and Y.S. Kurniawan, Y.S., AIP Conf. Proc., 1823, 020081 (2017), DOI: 10.1063/1.4978154

4. Y.S. Kurniawan, Y. Ramanda, K. Thomas, Hendra and T.D. Wahyuningsih, Indones. J. Chem., 17(2), 301(2017), DOI: $10.22146 /$ ijc.24891

5. Akhmad and Amir, IJEEP, 8(4), 13-20 (2018).

6. S. Kumar, N. Saxena and A. Mandal, J. Ind. Eng. Chem., 43, 106(2016), DOI: 10.1016/j.jiec.2016.07.055

7. R. Sharma, J. Singh and N. Verma, Biocatal. Agric. Biotechnol., 16, 132(2018), DOI: 10.1016/j.bcab.2018.07.028

8. P.C. Martins and V.G. Martins, Int. Biodeterior. Biodegradation, 127, 10(2018), DOI: 10.1016/j.ibiod.2017.11.005

9. B. Yuan and D.A. Wood, J. Petrol. Sci. Eng., 167, 287(2018), DOI: 10.1016/j.petrol.2018.04.018

10. C. Esene, N. Rezaei, A. Aborig and S. Zendehboudi, Fuel, 237, 1086(2019), DOI: 10.1016/j.fuel.2018.08.106

11. A.P. Karlapudi, T.C. Venkateswarulu, J. Tammineedi, L. Kanumuri, B.K. Ravuru, V.R. Dirisala and V.P. Kodali, Petroleum, 4(3), 241(2018), DOI: 10.1016/j.petlm.2018.03.007

12. H. Radnia, A. Rashidi, A.R.S. Nazar, M.M. Eskandari and M. Jalilian, J. Mol. Liq., 271, 795(2018), DOI: $10.1016 /$ j.molliq.2018.09.070

13. X. Wang, T. Cai, W. Wen and Z. Zhang, Fuel, 230, 418(2018), DOI: 10.1016/j.fuel.2018.05.047

14. J.C.S. Rosestolato, A. Perez-Gramatges, E.R. Lachter and R.S.V. Nascimento, Fuel, 239, 403(2019), DOI: $10.1016 /$ j.fuel.2018.11.027

15. L.A. Trujillo-Cayado, M.C. Alfaro and J. Munoz, Colloids Surf. A Physicochem. Eng. Asp.,536, 198(2018), DOI: 10.1016/j.colsurfa.2017.06.010

16. G.F.D. Ferreira, D.R.Q. Souza, R. Lima, A.K.C.L. Lobato, A.C.M. Silva and L.C.L. Santos, J. Petrol. Sci. Eng., 167, 674(2018), DOI: 10.1016/j.petrol.2018.04.048

17. S.K. Jangir and S. Acharya, Rasayan J. Chem., 7(1), 28(2014).

18. P. Senthilkumar, S.S. Dawn, C. Saipriya and A.V. Samrot, Rasayan J. Chem., 11(4), 1686(2018), DOI: 10.31788/RJC.2018.1144053

19. R. Awang, C.K. Whye, M. Basri, R. Ismail, R. Ghazali and S. Ahmad, J. Oil Palm Res., 18, 231(2006).

20. T.A.K. Wardhani, Undergraduate Thesis, Department of Chemistry, Universitas Gadjah Mada, Yogyakarta, Indonesia (2008).

21. V.R. Patel, G.G. Dumancas, L.C.K. Viswanath, R. Maples and B.J.J. Subong, Lipid Insight, 9, 1(2016), DOI: $10.4137 /$ LPI.S40233

22. Y.S. Kurniawan, M. Anwar and T.D. Wahyuningsih, Material Science Forum, 901, 135(2017). DOI:10.4028/www.scientific.net/MSF.901.135

23. S. Amalia, Thesis, Department of Chemistry, Universitas Gadjah Mada, Yogyakarta, Indonesia (2008).

24. K. Holmberg, B. Jonsson, B. Kronberg and B. Lindman, Surfactants and Polymers in Aqueous Solution, John Wiley and Sons, Ltd., London, p.459 (2002).

25. T. Munguia and C.A. Smith, J. Chem. Educ., 78(3), 343(2001), DOI: 10.1021/ed078p343

26. C.Y. Chang, S.J. Wang, I.J. Liu and Y.C. Chiu, J. Chin. Chem. Soc., 34(3), 243(1987), DOI: $10.1002 /$ jccs. 198700037

27. C.E.S. Muriningsih, Thesis, Department of Chemistry, Universitas Gadjah Mada, Yogyakarta, Indonesia (2009).

28. I.S. Khattab, F. Bandarkar, M.A.A. Fakhree and A. Jouyban, Korean J. Chem. Eng., 29(6), 812(2012), DOI: $10.1007 / \mathrm{s} 11814-011-0239-6$

[RJC-5140/2018] 